\title{
FACTORS OF PSYCHOLOGICAL INFLUENCE AFFECTING EMPLOYEES IN RIGA ESTATE MANAGEMENT COMPANY N083
}

V. Urbane ${ }^{1}$, Dr.chem. prof., J.Bērzinš̌ ${ }^{2}$, Docent (practical), J. Ieviňš ${ }^{3}$, Dr.oec. prof., $1,2,3$ Riga Technical University, Faculty of Engineering Economics and Management

\begin{abstract}
The aim of the study is to assess and improve the safety and health of workers at work. In order to achieve this goal, the labour protection system was analyzed at a management company (Zemgale Division). The authors used the risk assessment methods often applied in Latvia, survey of employees and have developed recommendations for improving the labour protection system.

Ergonomic risk assessment methods and psychoemotional factors have been analyzed. Based the analysis of the obtained results, proposals were developed for improvement of the labour protection system, which may be suitable also for other companies.
\end{abstract}

Key words: stress, occupational diseases, psychological climate.

JEL code: H51, J150

\section{Introduction}

People spend a lot of their life at work. During the process of work an employee is exposed to factors endangering the health and even life: physical (noise, vibration, radiation), chemical (hazardous substances and products), biological (bacteria, mushrooms, allergens etc.), psychoemotional (stress, disagreements at work, inadequate work); as well as to combinations of various factors.

The safe working conditions of an employee are regulated by the Labour Protection Law, the Cabinet of Ministers Regulations, ILO Regulations, as well as the European Union Framework Directives, which must be fulfilled by both the employer and the employee (Berger.A.A., 2011,Chapanis A., 1996, The Labour Protection law, 2002).

During the work process, a worker can develop illnesses, so-called occupational diseases, associated with representatives of a particular profession.

There is more talk about stress, psychoemotional overload, tension at work, lack of time, overload, work at night, overtime, conflicts, threats, poor relations with the employer and colleagues.

Creating a healthy psychological climate in a team is one of the key challenges for managers of all levels. A healthy climate is when all conflict situations are discussed and resolved. Therefore, it is important to more deeply evaluate the psychosocial risk in any organization in order to objectively assess the situation and to determine whether the psychoemotional state of the staff does not affect the quality and reputation of the organization's activities ( The Labour Law, 2002, The Labour Environment internace ..., 2007, Riga Stradins University..., 2011).

Since restoration of independence of the Republic of Latvia, a number of residential housing management companies have been established, which provided housing management and administration services for residential building owned by local governments. For customers' convenience, such companies were established in each microdistrict of Riga.

By the end of 2010, 15 municipal capital companies were operating in the administrative territory of Riga. Taking into account that 15 different companies managing dwelling houses owned by the local government had no the implemented and realized uniform principles of operation and management, a decision was made to establish LLC " $X$ " management company.

The chosen management company was established on 29 December 2010. Zemgale Division is one of few divisions of the management company, which over time has preserved the historically 
developed territorial area - both in the Soviet era and since restoration of independence of the Republic of Latvia it managed and administrated residential houses in Pardaugava, Zemgale Suburb of Riga.

Zemgale Division of the management company has established a labour protection system and provided its functioning and control; internal supervision of the work environment is carried out on a regular and qualitative basis at all stages of the work, preventive measures are implemented in the company, the employees are cooperating with the employer, are aware of the risks evaluation and participate in the implementation of labour protection measures. The study determined psychological factors in Estate management company that will help to improve afterwards wokers's conditions of labour and interralationship between employees and employers and consumers.

The aim of these pares is to analyse psycholigical factors effecting employees of Estate management company and to develop recommendations on how to improve the work conditions.

The Labour Protection Law states that the state policy in the field of labour protection is to arrange the working environment so as to avoid unsafe working conditions (Ozolina-Ozola, I., 2011, Riga Stradins University..., 2011).

Compliance with laws and regulations guarantees that employees subordinated to the employer will be ablebodied (Berger A.A., 2011, Chapanis A., 1996).

\section{Material and methods}

In their study, the authors used the following methods:

- abstract-logical method for separating the essential features of the studied object from least significant ones and for analyzing different alternative solutions;

- graphical method - for a visual illustration of data and for the presentation of the analysis data. Data so formatted is easily comparable;

- constructive method of calculations;

- monographic method - to collect and summarize information as well as to conduct a detailed study based on extensive literature review. Divisions of the management company implement the company's policy as well as realizes the vision of the company and its capital shareholder. The divisions provide high-quality services of management of residential apartment houses, implement an efficient use of financial resources for the maintenance and improvement of the housing stock.

The mission of the management company's Zemgale Division is to fulfill the mission of the company: to carry out a high-quality and uninterrupted management of residential buildings, promoting to improve technical condition of these houses.

Strategic objectives of the management company are structured in three groups:

1) objectives associated with the implementation of the functions of the local government, which are related to the fulfillment of duties specified in agreements on management of residential houses: provision of mandatory management activities and guidelines specified in the policy planning documents;

2) objectives associated with commercial activity, which are not directly related to the but are related to the improvement of the company's internal functioning, capacity growth, improvement of management processes, introduction of quality management system, attraction of new clients etc.;

3) financial objectives, which include the forecasts for indicators of net turnover, investments, personnel costs, number of employees, profit or loss etc. 
From the company's standpoint, the vision and mission shall mean:

- Vision: The management company is the largest and most professional housing manager in Riga with highly qualified staff who provide a high-quality and fast service for inhabitants of residential apartment houses, as well as innovative management methods, involving the inhabitants in the process of improving their services.

- Mission: Provide the services of management of residential houses (technical maintenance of buildings, sanitary care of attached land plots etc.), of which quality satisfies the inhabitants of residential apartment houses and other clients (Berger A.A., 2011).

The company provides the following residential house management activities (The Labour Law, 2002):

- Sanitary maintenance of residential houses;

- Heating, water supply and sewerage, domestic waste disposal services;

- Provision of electric power supply for the co-owned part of residential buildings;

- Inspection, maintenance and routine repair of residential houses and their communications. Activities of the division can be split into four groups (Unpublished materials of ... ):

4) Providing a continuous and high-quality management of residential apartment houses (management of home appliances and communications; management and sanitation of houses and their attached territories; visual inspection of houses; provision of other management services);

5) Providing the technical improvement of managed buildings and implementation of energy efficiency measures (technical improvement of houses; implementation of home energy efficiency measures; technical improvement of house-related areas);

6) Customer service quality improvement (direct customer service; organization of educational and informative events for customer; development of IT solutions for improvement of customer service; public relations);

7) Providing the competitiveness of the company (application of modern management principles; improvement of staff professionalism and experience; improvement of the division work organization; improvement of the material and technical base and infrastructure).

The tasks of Zemgale Division activity are in line with the goals and objectives of the management company and the Law on Residential Housing Management.

The psychoemotional climate in a company like a management enterprise is very important because people with very different background and age working there and often they are not able to communicate with each other during the working day, which causes many problems in the team.

\section{Description of create scales}

In order to assess the psychological situation in the management company's Zemgale Division, the author of the work has chosen three groups of employees, and members of each group were asked to complete several tests, one of them being the Psychological Climate Scale (see Table 1).

Creating a healthy psychological climate in the team is one of the main tasks of the managers of all levels. A healthy climate means that all conflict situations are discussed and solved. In order to assess the psychological climate of the work group, the author used the expert assessment methods and conducted an anonymous survey of employees of groups of certain professions (Kalnina, L., 2012, Ozolina-Ozola, I., 2011).

The study was participated by three groups of employees (Unpublished materials of ...): 
1) Yardkeepers - cleaners;

2) Office workers;

3) Working group (engineers, roofers, electricians, plumbers, auxiliary workers etc.)

Table 1

Psychological climate assessment scale

(modified by the author from Kalkis, 2008, 194)

\begin{tabular}{|c|c|c|}
\hline Features of healthy psychological climate & $\begin{array}{l}\text { Scale } \\
5 \text { to } 1\end{array}$ & Features of unhealthy psychological climate \\
\hline $\begin{array}{l}\text { 1. In the workday beginning, the } \\
\text { colleagues have a good mood, they take } \\
\text { inspiration and vigour. }\end{array}$ & & $\begin{array}{l}\text { 1. Most of employees appear at work in } \\
\text { everyday "routine" mood, they do not feel joy. }\end{array}$ \\
\hline $\begin{array}{l}\text { 2. Most of us are happy about the } \\
\text { possibility of contacting each other. }\end{array}$ & & $\begin{array}{l}\text { 2. The teammates are indifferent to mutual } \\
\text { contact. }\end{array}$ \\
\hline $\begin{array}{l}\text { 3. Success of each team member really } \\
\text { brings joy to the others. }\end{array}$ & & $\begin{array}{l}\text { 3. Anybody's success makes the others } \\
\text { displeased, envious. }\end{array}$ \\
\hline $\begin{array}{l}\text { 4. A newcomers to our work team will be } \\
\text { treated with grace. }\end{array}$ & & $\begin{array}{l}\text { 4. Our newcomers will feel like a stranger for a } \\
\text { long time. }\end{array}$ \\
\hline $\begin{array}{l}\text { 5. In case of trouble we are trying to find } \\
\text { out the circumstances. }\end{array}$ & & $\begin{array}{l}\text { 5. In case of trouble in our team everyone will } \\
\text { try to blame the other or find "the guilty". }\end{array}$ \\
\hline $\begin{array}{l}\text { 6. Presence of a superior activates our ease } \\
\text { and liberty. }\end{array}$ & & $\begin{array}{l}\text { 6. In the presence of a superior many feel tense } \\
\text { and confused. }\end{array}$ \\
\hline $\begin{array}{l}\text { 7. We usually discuss with each other our } \\
\text { family joys and sorrows. }\end{array}$ & & $\begin{array}{l}\text { 7. Many of us do not want to discuss our } \\
\text { problems with others. }\end{array}$ \\
\hline $\begin{array}{l}\text { 8. Sudden invitation to a superior does not } \\
\text { cause negative emotions in most } \\
\text { employees. }\end{array}$ & & $\begin{array}{l}\text { 8. Sudden invitation to a superior causes } \\
\text { negative emotions in many of us. }\end{array}$ \\
\hline $\begin{array}{l}\text { 9. Violator of labour discipline } r \text { affects the } \\
\text { other teammates. }\end{array}$ & & $\begin{array}{l}\text { 9. Violator of labour discipline reports only to the } \\
\text { superior. }\end{array}$ \\
\hline $\begin{array}{l}\text { 10. When making critical remarks, most of } \\
\text { us do it delicately. }\end{array}$ & & $\begin{array}{l}\text { 10. Critical notes sound openly or secretly } \\
\text { offensive. }\end{array}$ \\
\hline $\begin{array}{l}\text { 11. Appearance of a superior brings } \\
\text { positive emotions to us. }\end{array}$ & & $\begin{array}{l}\text { 11. Appearance of a superior arises dislike in } \\
\text { many of us. }\end{array}$ \\
\hline $\begin{array}{l}\text { 12. "Transparency" is the norm in the } \\
\text { team. }\end{array}$ & & 12. "Transparency" is still very far away. \\
\hline $\begin{array}{l}\text { 13. Favourable and trustful atmosphere } \\
\text { rules in relations with clients. }\end{array}$ & & $\begin{array}{l}\text { 13. Communication with clients creates obvious } \\
\text { or masked nervousness. }\end{array}$ \\
\hline $\begin{array}{l}\text { 14. We are pleased to provide information } \\
\text { and services in the framework of our } \\
\text { duties. }\end{array}$ & & $\begin{array}{l}\text { 14. When it comes to fulfilling own work tasks, I } \\
\text { experience stress each time contacting with the } \\
\text { clients. }\end{array}$ \\
\hline $\begin{array}{l}\text { 15. Sudden invitation to or appearance of a } \\
\text { client does not cause negative emotions. }\end{array}$ & & $\begin{array}{l}\text { 15. Sudden invitation to or appearance of a } \\
\text { client causes negative emotions. }\end{array}$ \\
\hline $\begin{array}{l}\text { 16. Appearance of clients gives us positive } \\
\text { emotions. }\end{array}$ & & $\begin{array}{l}\text { 16. Appearance of clients is a source of dislike } \\
\text { for many. }\end{array}$ \\
\hline $\begin{array}{l}\text { 17. It seems to me that the clients } \\
\text { appreciate my work and I feel their positive } \\
\text { attitude. }\end{array}$ & & $\begin{array}{l}\text { 17. It seems to me that the clients do not } \\
\text { appreciate my work and I feel their negative and } \\
\text { humiliating attitude. }\end{array}$ \\
\hline
\end{tabular}

The survey involved of a total of 150 employees of average age 26 to 50 . The assessment should be done by a 5-point system, entering the value of the points depending on the employee's situation assessment according to the put questions. The total score is within the range 85 to 17 points (85-68 acquired points - healthy atmosphere; 67-35 - medium atmosphere; 34-17 unhealthy work atmosphere is ruling in the team). Summarizing the answers of the respondents, it is possible to judge not only the general psychological climate in the collective but also in what direction some changes should be made in order to improve the psychological atmosphere. For example, whether there are disagreements with the management, colleagues or clients. The author 
used the psychological climate scale and adapted it to the specifics of the organization's activity, included questions 13 to 17 on contact with the clients (see Table 1).

The following results were obtained by evaluating and summarizing the data obtained (see Table 2). In Table 1 the received points are grouped by jobs.

\section{Research results and discussion}

The first part discusses the psyhoemotional climate in a company like management enterprise with vary backgraund and age working there.

The second part presents the main results of study,folowing by conclution some recommendations suggested by authors.

Results of psychological climate assessment (created by the author, 2017)

\begin{tabular}{|l|c|c|c|}
\hline \multicolumn{1}{|c|}{ Job groups } & $\begin{array}{c}\text { Number of employees } \\
\text { who received 17-34 } \\
\text { points }\end{array}$ & $\begin{array}{c}\text { Number of employees } \\
\text { who received 35-67 } \\
\text { points }\end{array}$ & $\begin{array}{c}\text { Number of employees } \\
\text { who received 68 - 85 } \\
\text { points }\end{array}$ \\
\hline Office workers & - & 47 & 3 \\
\hline $\begin{array}{l}\text { Yardkeepers - } \\
\text { cleaners }\end{array}$ & - & 38 & 12 \\
\hline Working group & - & 43 & 7 \\
\hline
\end{tabular}

Summarizing the acquired data, the above results were obtained and presented in Table 2 where the employees are grouped by their jobs and the points received are shown for each group. The summarized points of for all job groups is generally between 35 and 67, which corresponds to the average psychological climate, but there were also respondents in each group who scored between 68 and 85 evidencing a healthy psychological climate.

In continuation of the work, the author carried out a psychoemotional assessment analysis for each job group separately (see Figure 1, Figure 2, Figure 3), identifying for each group the most problematic sphere, which would require certain improvements and solutions.

Psychoemotional risk assessment by the psychological climate scale for the Working Group in Figure 1 demonstrates that the respondents very low evaluated the following features:

- In case of trouble in our team everyone will try to blame the other or find "the guilty" - 1 employee,

- In the presence of a superior many feel tense and confused - 5 employees;

- Many of us do not want to discuss our problems with others - 36 employees;

- Sudden invitation to a superior causes negative emotions in many of us - 36 employees feel moderately;

- Appearance of a superior arises dislike in many of us - 9 employees;

- Appearance of clients is a source of dislike for many - 43 employees have noted moderately,

- It seems to me that the clients do not appreciate my work and I feel their negative and humiliating attitude: in each 12 - bad and 37 - moderately, as noted by the respondents.

- Psychoemotional risk assessment based on the psychological climate scale for the Yardkeepers Cleaners in Figure 2 shows that employees of this group are more negative than positive in contacting the clients as well as have evident problems with the management (see Figure 2). 


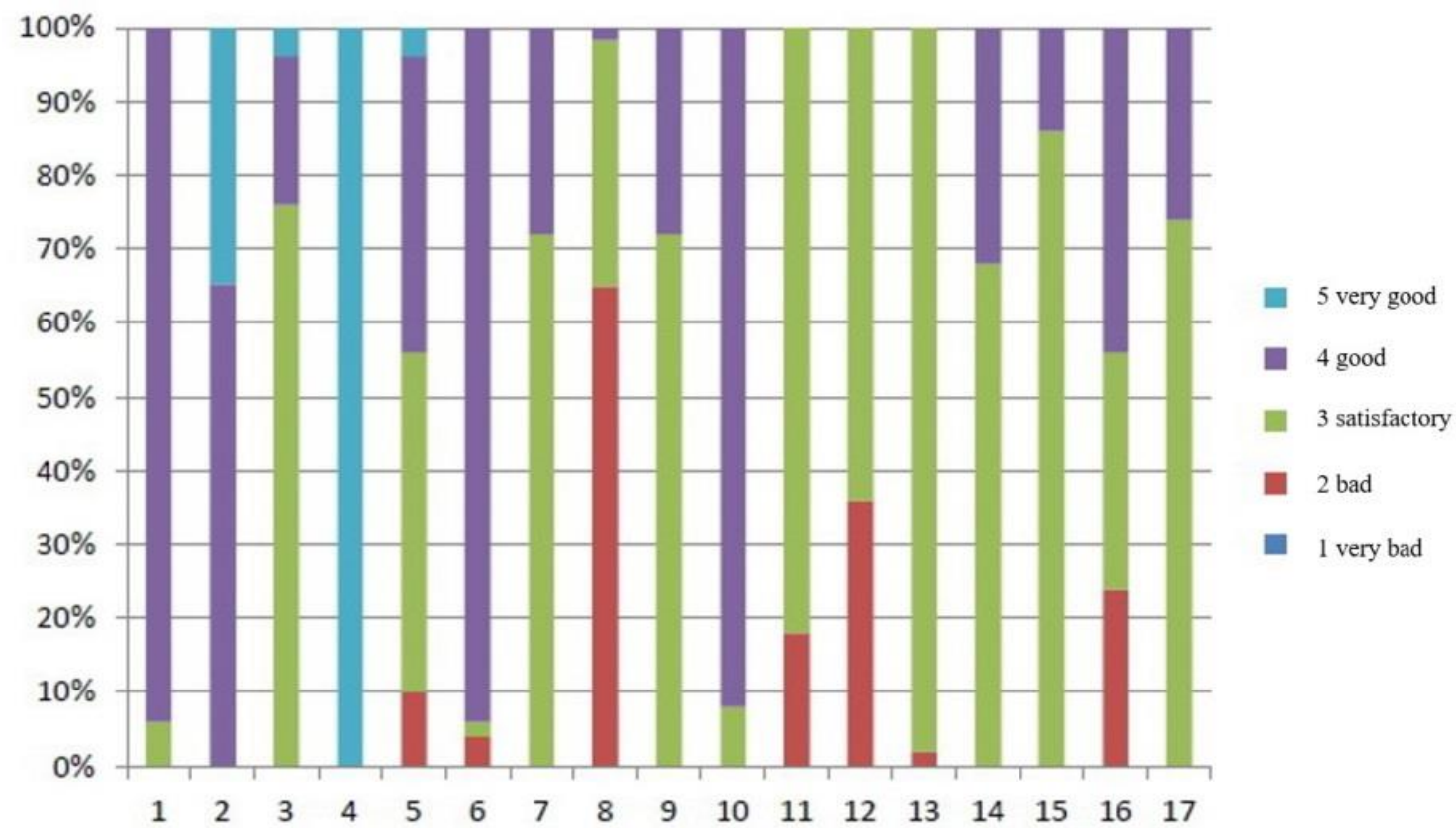

Source: author's calculations based on questionnares.

Fig. 1. Psychoemotional risk assessment based on the psychological climate scale for the Working Group, \% (created by the work author, 2017).

Psychoemotional risk assessment based on the psychological climate scale for the Yardkeepers Cleaners in Figure 2 demonstrates that the respondents very low evaluated the following features:

- In case of trouble the colleagues blamed each other - 11 employees;

- Many employees do not want to discuss their problems with others - 32 employees;

- Invitation to a superior causes negative emotions - 19 employees;

- Communication with customers creates nervousness - 8 employees;

- Sudden invitation to or appearance of the client causes negative emotions - 38 employees;

- Appearance of clients creates dislike - 47 employees.

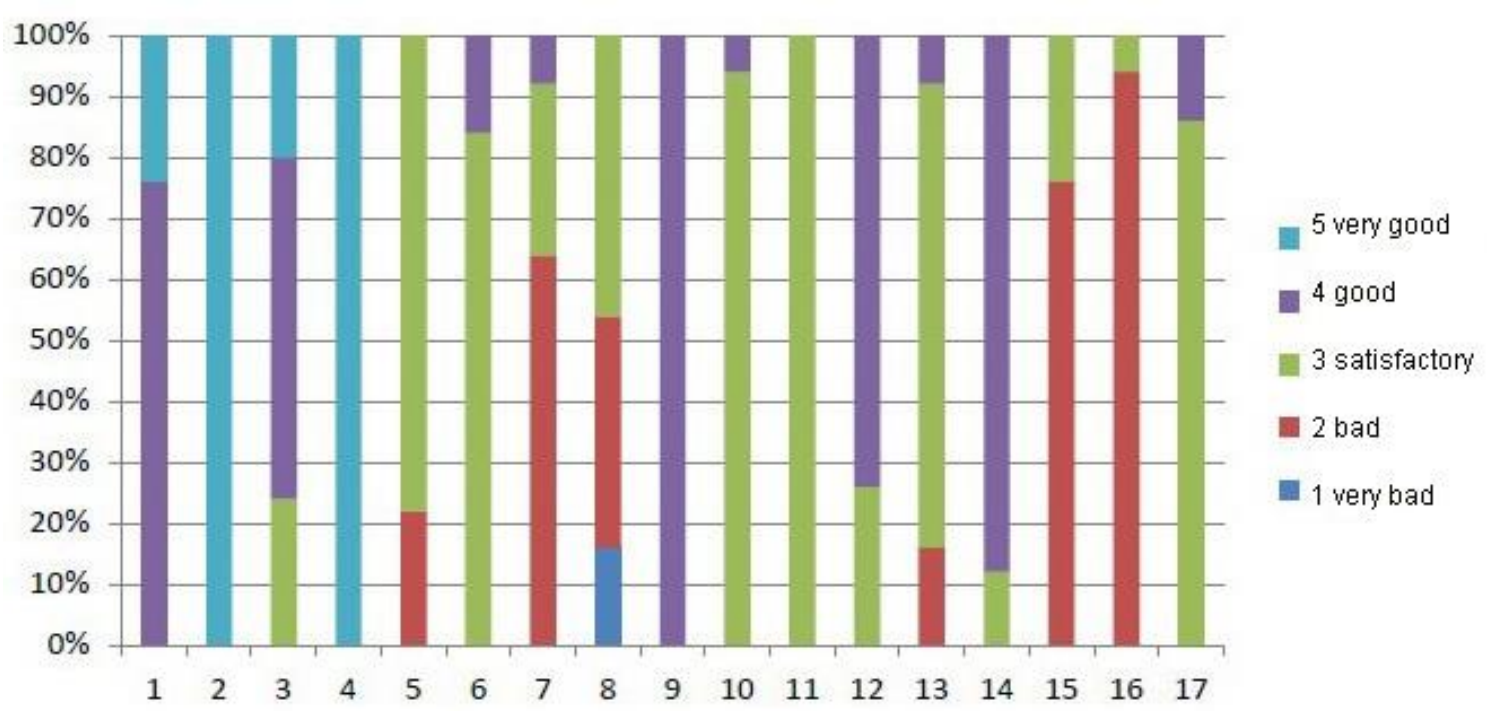

Source: author's calculations based on questionnares.

Fig. 2. Psychoemotional risk assessment based on the psychological climate scale for the Yardkeepers - Cleaners, \% (created by the work author, 2017).

It can be seen on Figure 3 that employees of this group have most negatively marked just the contact with clients because in their everyday work just the office staff most of all are working with the residents - apartment owners, both at reception time and by telephone (see Fig. 3). 


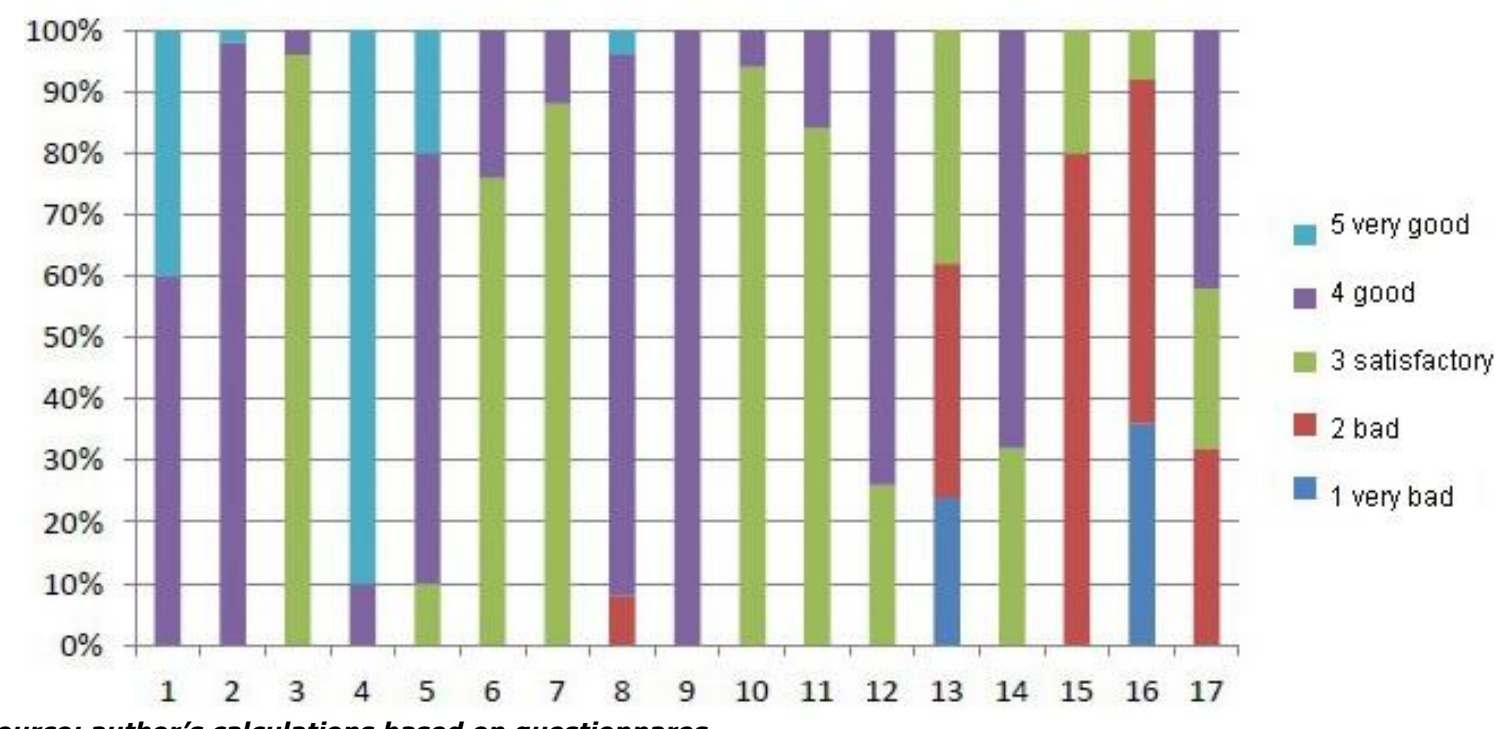

Source: author's calculations based on questionnares.

Fig. 3. Psychoemotional risk assessment based on the psychological climate scale for the Office Staff, \% (created by the work author, 2017).

Psychoemotional risk assessment based on the psychological climate for the Office staff is shown in Figure 3 where it can be seen that the respondents very low evaluated the following features:

- Sudden invitation to a superior - 8 employees;

- Contact with clients causes obvious or masked nervousness or dislike - 25 employees;

- Sudden invitation to or appearance of a client arises negative emotions - 40 employees;

- Appearance of clients arises dislike in many - 46 employees;

- We think that the clients do not appreciate this work - 16 employees.

In addition to the psychoemotional climate assessment, the authors gave the same employees a test that identified the signs of depression.

Depression test results can be viewed on Figure 4 and demonstrate that no one needs consultation by a specialist but some have signs of moderate depression - total 52 employees out of 150 being surveyed (see Appendix No. 4 for the questionnaire).

The survey involved a total of 150 employees of average age 26 to 50 . The is a common idea that the work in such kind of companies is not stressed, safe. However. Our study has proved the opposite.

Summarizing the results of the depression test for the employees, the author concludes that in general the participants of the Office Staff group feel worst of all psychoemotionally, that is those who are most often in contact with the clients. The author explains it by a large amount of work and the number of apartment owners as each house manager administers 50 to 100 residential buildings; respectively, there is also a very large number of apartment owners, of which every third one one wants to visit the management company and express their wishes, raise voice, sometimes threaten etc., so often the situation in the working environment causes a depressing mood. 
Do you feel the consciousness of guilt or a permanent oppression?

Do you feel that the life has become uninteresting?

Do you feel concentration problems or permanent doubts?

Do you feel changes in your appetite - is it increased or reduced?

Do you feel oppression, emotional emptiness?

Are you oppressed by sleepiness or insomnia?

Do you feel lag of consciousness, slowness, slow reaction, fulfilment of simple jobs

Do you feel trouble, unrest, you cannot rest?

Do you feel tiredness, lack of energy?

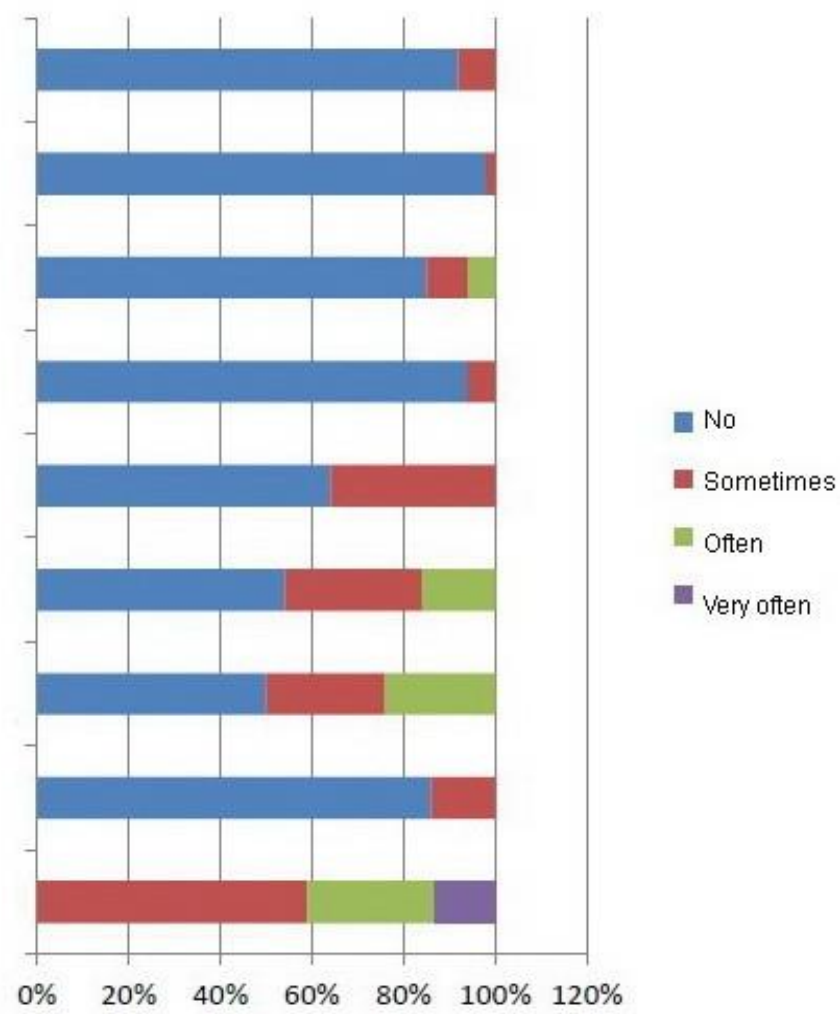

Source: author's calculations based on questionnares.

Fig. 4. Results of workers' depression test (created by the author, 2017).

\section{Conclusions}

Summarizing the data on psychoemotional risks, the obtained results show that the summarized score for groups of job is mainly within 35 and 67, which corresponds to the average psychological climate, as well as there were respondents in each group of job who scored points 68-85, which evidences the healthy psychological climate.

The psychoemotional risk assessment according to the psychological climate scale is similar for all groups. The answers given indicate that employees have more negative than positive in contacts with the clients as well as the problems with managements are evident in the answers given.

Depression test results demonstrate that no one needs consultation by a specialist but some have signs of moderate depression - total 52 employees out of 150 being surveyed.

In general the participants of the Office Staff group feel worst of all psychoemotionally, that is those who are most often in contact with the clients, which is explained by a large volume of work and visits of negatively disposed apartment owners, so often the situation in the work environment causes a depressive mood.

This study allows to ray attention to conditions to work effectively for Estimate management companies both in Riga and all Republic cities.

The division manager should make changes in own style of work, paying more attention to the wellbeing of workers. It is desirable to find time for negotiations and problem solving, arrange weekly meetings to discuss work to be done, make decisions collectively rather than deciding and criticizing at sole discretion, provide employees with information on solutions reduction of working load, which will improve the employees' work process and quality. 
In order to ensure good relationships between the office workers and the clients, the division manager should organize restrictions on the customer reception times, regulate a uniform distribution of work, employ the trainees, appoint the office workers to attend the motivation courses, establish additional payments or pay bonuses for positive work results.

As the recieved data of the study are not published, the authers are going to supply this information both the Head of the enterprese where the investigation took place, and Riga city authority. The authors hope that this will help to accept strategical important solutions on development and personnel's, occupied in this sphear, motivation.

\section{Bibliography}

1. Belcikovs, J.,\& Praude, V., (2001) Management. Riga: Vaidelote Publishing.

2. Berger A.A (2011). Media and Communication Research Methods: An Introduction to Qualitative and Quantitatiive Approaches. Second Edition. London: Sage Publications Ltd.p.205

3. Chapanis A (1996). Human factors in systems engineering. New York; Wiley 332p.

4. The Labour Protection Law (2002) [online] LR Law ,Riga 2002. 20 Juny, Latvian Journal. Internet site Law.Iv [ viewed 2017.4.May] . Available:https://likumi.Iv/doc.php

5. The Labour and risks in Latvia 2012-2013, (2016).[online] Latvian Labour employer Confederation [viewed 20174 May]. Available: http://www.iddk.Iv/wp-content

6. The Labour Law.(2002) [online]LR law, Riga 2001. 20 Juny, Latvian Journal, Internet site, Law Lv [viewed 20174 May], Available: https://likumi.lv/doc.php

7. The Process of Internal Monitoring of Working Environment (2007) [online] LR Cabinet Regulation 660.Riga 20075 October, Latvian Journal, Internet site Likumi.Iv [viewed 20174 May], Available: https://likumi.Iv/doc.php

8. Eglïte, M (2012) The Labour Medicina.Riga: Riga Stradins University.834 p.

9. Kalnina, L. (2012) Modernize the labour relations. Riga: Latvian Free Trade Union Confederation Publishing.

10. Kalkis, V. (2008) The labour Environment Risk Assessment Methods, Guidelines, Risk Matrices, Examples, Advices and Softwares. Riga: Latvian Education Fund. 242 p.

11. Keil, M., Amershi, B., Holmes, S., Jablonski, H., Luthi, E., Matoba, K., Plett, A., Unruh, K. (2007) Diversity Management Training Handbook. EU: International Society for Diversity Management.

12. Ministry of Welfare (2010). Psychosocial environment. Riga: Latvian Free Trade Union.

13. Ministry of Welfare (2016, March 14) Psihoemocionālie riska faktori [Psycho-emotional risk factors]. Retrieved from: http://www.Im.gov.IV/upload/aktualitates/null/psihoemocionalie_raksts1.pdf

14. Ozolina - Ozola, I. (2011) Issues of Human Resource Management Effectiveness Measurement. Economics and Business, 21, 67-75.

15. Riga Stradins University (2011) Stress at work or psycho-emotional risk factors. Riga: Riga Stradins University, Occupational Safety and Environmental Health Institute, 24.

16. Unpublished materials of the management company.

17. Wilson, J.R., Haines, H.M. (2001) Participatory Ergonomics. International Encyclopedia of Ergonomics and Human Factors. Publisher: Karwowski, pp $1282-1286$. 